\title{
Bio- efficacy of Oilcake Extracts to Control Macrophomina phaseolina (Tassi) Goid Causing Dry Root Rot Disease in Groundnut (Arachis hypogaea L.)
}

\author{
S. Kanmani ${ }^{1 *}$, N. Rajinimala ${ }^{1}$, J. Sheela ${ }^{1}$ and B. Jeberlin Prabina ${ }^{2}$ \\ ${ }^{1}$ Department of Plant Pathology, Agricultural college and Research Institute, Killikulam, \\ Vallanadu- 628252, Tamil Nadu Agricultural University, Tamil Nadu, India \\ ${ }^{2}$ Department of Soil Science and Agricultural Chemistry, Agricultural College and \\ Research Institute, Killikulam, Vallanadu- 628 252, Tamil Nadu Agricultural University \\ Tamil Nadu, India \\ *Corresponding author
}

\section{A B S T R A C T}

\section{Keywords \\ Arachis hypogaea, Bio-control, Dry root rot, Oil cake extracts, Macrophomina phaseolina}

\section{Article Info}

Accepted: xx July 2020 Available Online: xx August 2020
Dry root rot disease hinders the cultivation of groundnut crop and leads to major yield loss. Chemical control of this pathogen renders harmful effect on soil microbes thereby depleting the soil quality. Considering this, an attempt was made to manage groundnut dry root rot disease in a natural way. Different oil cake extracts were tested for their antifungal activity against groundnut dry root rot pathogen Macrophomina phaseolina through poisoned food technique. Among the seven oil cake extracts tested under in vitro condition, neem cake extract found effective against Macrophomina phaseolina with minimum mycelial growth of $4.23 \mathrm{~cm}$ and maximum mycelia inhibition of 52.90 per cent followed by coconut cake extract recorded mycelial growth of $4.47 \mathrm{~cm}$ and mycelial inhibition of 50.33 per cent against control at 10 per cent concentration. But under 15 per cent concentration, groundnut cake extract was proved effective against Macrophomina phaseolina with minimum mycelial growth of $3.20 \mathrm{~cm}$ and maximum mycelial inhibition of 65.00 per cent followed by neem cake extract recorded the mycelial growth of $4.40 \mathrm{~cm}$ and mycelial inhibition of 51.10 per cent.

\section{Introduction}

Groundnut or Peanut is a crop species which belongs to legume or Bean family. This crop is called by several other names viz., earth nuts, groundnuts, goober peas, pig nuts, pygmy nuts and monkey nuts. It is not a nut, but rather a legume despite its name and appearance. Being major oil seed crop in
India, this plays major role in bridging oil deficit in India. It is cultivated in both Kharif and Rabi. Exports of Groundnut from India to World market ranges up to $4,89,187 \mathrm{MT}$ worth of Rs.3,298.31 crores during the year 2018-19. India ranks first in the world in area to produce groundnut which contributes about $40 \%$ of the total area (APEDA Annual report, 2019). India ranks second in groundnut 
production with 9.25 million tonnes which contributes $33.30 \%$ of the world's production. The average productivity of the groundnut in India is about $1893 \mathrm{~kg} / \mathrm{ha}$. It is grown in an area of about 48 Lakh hectares (Agriculture Indiastat, 2018-19). It becomes a major oil (40-49\%) and protein source (20\%) for consumption. Economically important seed and seedling disease of groundnut enlisted are collar rot/seedling blight, stem rot / Scelortium wilt, dry wilt or dry root rot.

These diseases majorly found to cause seedling mortality resulting in patchy crop stand and reduces the yield of the crop from 25-50\% (Kapur and Chohan, 1974). Among these diseases, dry root rot caused by $M$. phaseolina (Tassi.) Goid has been found to cause major losses from seedling stage to maturity of the crop with 35 to 60 per cent disease severity and 70 per cent yield loss (Ray and Kumar, 2008). Khamari et al., (2017) reported that the indiscriminate use of fungicides to manage this disease leave residues on the soil and pose major health threats to the society. Nearly 200 plant pathogens are found to be resistant towards various chemicals including fungicides (Varma and Dubey, 1999). Hence there is an urgent need to find an alternative tactic to manage the disease. Considering the economic importance of the crop and serious effects of the dry root rot pathogen, a study was carried out to manage the dry root rot pathogen in vitro by using various oil cake extracts.

\section{Materials and Methods}

The pathogen causing charcoal rot or dry root rot in groundnut crop was isolated from infected stem portions using tissue segment method. The culture was purified and maintained in Potato Dextrose Agar (PDA) medium for further studies. Fresh culture which is five days old was used in the study.
The antifungal potency of seven different oil cakes viz., Castor cake, Coconut cake, Cotton cake, Groundnut cake, Neem cake, Sesame cake, Mixture cake (Cotton cake and sesame cake) was tested against groundnut root rot pathogen $M$. phaseolina through poisoned food technique at 10 per cent and 15 percent concentration.

The aqueous extracts of different oil cakes mentioned above were obtained by suspending $40 \mathrm{gm}$ of ground oil cake in 150 $\mathrm{ml}$ of sterile distilled water and left soaked for 10 days. After 10 days, the contents were filtered through three layered sterile muslin cloth. Then the extracts were centrifuged at $10000 \mathrm{rpm}$ for 15 minutes and supernatant obtained was used as standard solution (100\%) (Meena et al., 2014). For in vitro studies, the extracts were diluted to $10 \%$ and $15 \%$ concentrations. Each oil cake extracts were taken at $10 \mathrm{ml}$ and $15 \mathrm{ml}$ quantities and mixed with $90 \mathrm{ml}$ and $85 \mathrm{ml}$ molten PDA to get 10 per cent and 15 per cent concentrations. They were mixed thoroughly in conical flasks and safely plugged with nonabsorbent cotton and further sterilized by using autoclave at 15 psi for 15 minutes. Then the poisoned media were poured in Petri plates and inoculated with fresh culture discs of $M$. phaseolina (test pathogen) and incubated at room temperature. Simultaneously, Petri plates with PDA which does not contain any oil cake extract kept as control. Three replications were maintained for each treatment. Observations on mycelial growth of the pathogen were taken and mycelial inhibition percentage over control was calculated using Vincent formulae (Vincent, 1947).

$I=\frac{\mathrm{C}-\mathrm{T}}{\mathrm{C}} \times 100$

Where, $\mathrm{I}=$ Mycelial Inhibition Percentage $\mathrm{C}=$ Mycelial growth of the pathogen in 
Control (in cm)

$\mathrm{T}=$ Mycelial growth of the pathogen in Treatment (in cm)

\section{Results and Discussion}

The aqueous extracts of seven different oil cakes were tested for their inhibitory activity against groundnut dry root rot pathogen $M$. phaseolina at 10 per cent and 15 per cent concentrations and the results are appended in Table 1. Among the seven oil cake extracts tested against $M$. phaseolina under in vitro condition, neem cake extract found effective against $M$. phaseolina with minimum mycelial growth of $4.23 \mathrm{~cm}$ and maximum mycelia inhibition of 52.90 per cent followed by coconut cake extract recorded mycelial growth of $4.47 \mathrm{~cm}$ and mycelial inhibition of 50.33 per cent against control at 10 per cent concentration (Figure 1). But under 15 per cent concentration, groundnut cake extract was proved effective against $M$. phaseolina with minimum mycelial growth of $3.20 \mathrm{~cm}$ and maximum mycelial inhibition of 65.00 per cent followed by neem cake extract recorded the mycelial growth of $4.40 \mathrm{~cm}$ and mycelial inhibition of 51.10 per cent. Mixture cake recorded the least inhibition of 33.40 per cent and 27.00 per cent against control at 10 and $15 \%$ respectively (Figure 2 ).

Table.1 Bioefficacy of different oil cake extracts on growth of M. phaseolina in vitro

\begin{tabular}{|c|c|c|c|c|c|}
\hline \multirow[t]{2}{*}{$\begin{array}{l}\text { Sl. } \\
\text { No. }\end{array}$} & \multirow[t]{2}{*}{$\begin{array}{l}\text { Oil cake } \\
\text { extracts }\end{array}$} & \multicolumn{2}{|c|}{$\begin{array}{l}\text { Mycelial growth of the pathogen } \\
(\mathbf{c m})^{*}\end{array}$} & \multicolumn{2}{|c|}{$\begin{array}{l}\text { Percent inhibition over } \\
\text { control }(\%)^{*}\end{array}$} \\
\hline & & $10 \%$ & $15 \%$ & $10 \%$ & $15 \%$ \\
\hline 1 & Castor cake & $4.70^{b}$ & $5.20^{\mathrm{c}}$ & $\begin{array}{c}47.77 \\
(43.68)^{\mathrm{b}}\end{array}$ & $\begin{array}{c}42.22 \\
(40.50)^{c}\end{array}$ \\
\hline 2 & Coconut cake & $4.47^{\mathrm{ab}}$ & $5.80^{d}$ & $\begin{array}{c}50.33 \\
(45.17)^{\mathrm{ab}}\end{array}$ & $\begin{array}{l}35.55 \\
(36.12)^{d}\end{array}$ \\
\hline 3 & Cotton cake & $5.26^{\mathrm{c}}$ & $5.26^{\mathrm{c}}$ & $\begin{array}{c}41.50 \\
(40.06)^{\mathrm{c}}\end{array}$ & $\begin{array}{c}41.55 \\
(40.08)^{c}\end{array}$ \\
\hline 4 & Groundnut cake & $5.50^{c}$ & $3.20^{\mathrm{a}}$ & $\begin{array}{c}38.8 \\
(38.54)^{\mathrm{c}}\end{array}$ & $\begin{array}{c}65.00 \\
(53.37)^{\mathrm{a}}\end{array}$ \\
\hline 5 & Neem cake & $4.23^{\mathrm{a}}$ & $4.40^{b}$ & $\begin{array}{c}52.9 \\
(46.68)^{\mathrm{a}}\end{array}$ & $\begin{array}{l}51.10 \\
(45.40)^{b}\end{array}$ \\
\hline 6 & Sesame cake & $4.51^{\mathrm{ab}}$ & $5.80^{d}$ & $\begin{array}{c}49.8 \\
(44.92)^{\mathrm{ab}}\end{array}$ & $\begin{array}{l}35.00 \\
(36.12)^{d}\end{array}$ \\
\hline 7 & Mixture cake & $5.89^{d}$ & $6.60^{\mathrm{e}}$ & $\begin{array}{c}33.4 \\
(33.95)^{\mathrm{d}}\end{array}$ & $\begin{array}{l}27.00 \\
(31.03)^{\mathrm{e}}\end{array}$ \\
\hline \multirow[t]{4}{*}{8} & Control & 9.00 & 9.00 & - & - \\
\hline & SEd & 0.13 & 0.13 & 0.84 & 0.88 \\
\hline & C.D(0.05) & 0.27 & 0.28 & 1.79 & 1.87 \\
\hline & $\mathrm{CV}(\%)$ & 2.91 & 2.87 & 2.81 & 3.06 \\
\hline
\end{tabular}


Fig.1 Bioefficacy of different oil cake extracts on the growth of M. phaseolina in vitro at $10 \%$ concentration
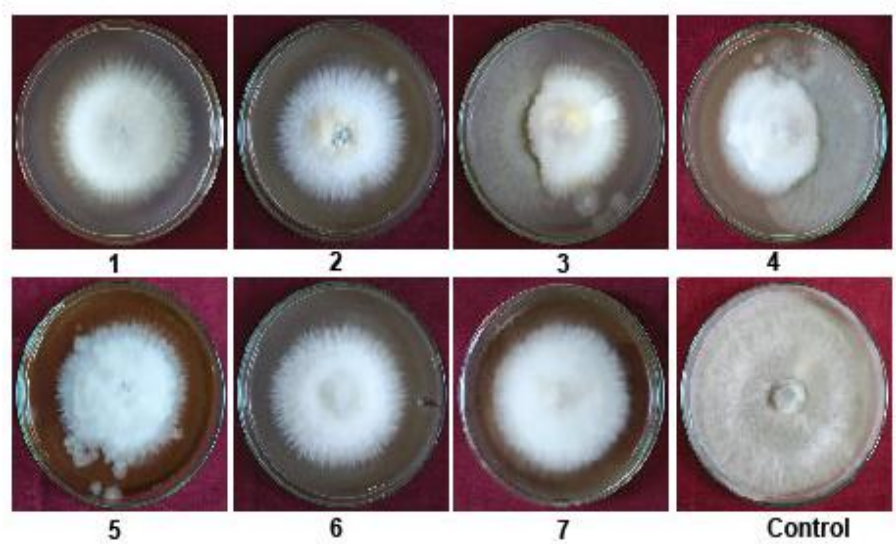

$$
\begin{aligned}
& 1 \text { - Castor cake } \\
& 2 \text { - Coconut cake } \\
& 3 \text { - Cotton cake } \\
& 4 \text { - Groundnut cake } \\
& 5 \text { - Neem cake } \\
& 6 \text { - Sesame cake } \\
& 7 \text { - Mixture cake }
\end{aligned}
$$

Fig.2 Bioefficacy of different oil cake extracts on the growth of $M$. phaseolina in vitro at $15 \%$ concentration

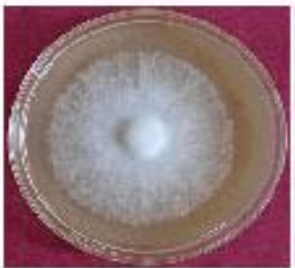

1

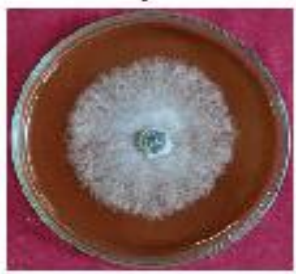

5

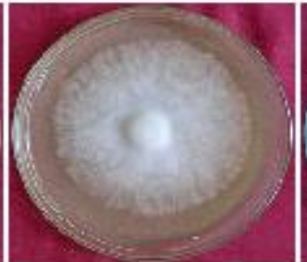

2

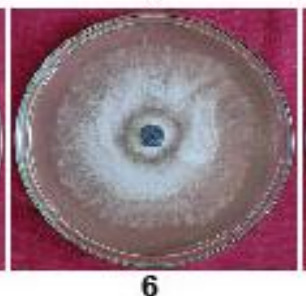

6

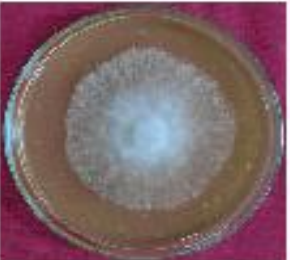

3

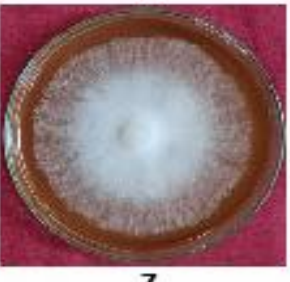

7

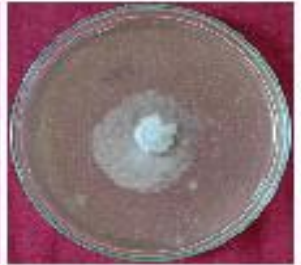

4

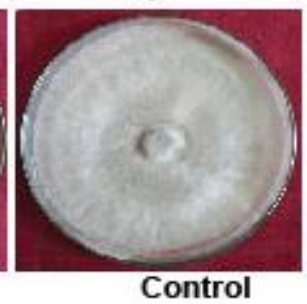

1 - Castor cake

2 - Coconut cake

3 - Cotton cake

4 - Groundnut cake

5 - Neem cake

6 - Sesame cake

7 - Mixture cake 
Several scientists have recorded the efficacy of different oil cake extracts against $M$. phaseolina. Chavan (2006) reported the efficacy of groundnut cake and neem cake extracts against the growth of $M$. phaseolina in vitro. They found to have mycelial inhibition percentage of 70.00 and 46.88 respectively over control. Dhingani et al., (2013) tested four organic extracts were tested against $M$. phaseolina by poisoned food technique in vitro. Significantly least growth of mycelium and maximum mycelium inhibition was recorded in extracts of neem cake $(59.40 \%)$ followed by farm yard manure (42.56 \%). Meena et al., (2014) reported the antifungal activity of neem oil cake and mustard oil cake extracts on $M$. phaseolina. It is found that maximum mycelial inhibition is exhibited by neem cake extract at 20 per cent with 52.40 per cent mycelial inhibition followed by 42.61 per cent and 29.60 per cent with concentrations of 15 per cent and 10 per cent respectively. Jha et al., (2000) tested different oil cake extracts for their efficacy against $M$. phaseolina and recorded that neem cake and pungam cake exhibited maximum mycelial inhibition of 63.40 per cent and 71.9 per cent at 10 per cent concentration.

In conclusion from the present study it was concluded that the groundnut oil cake extract at 15 per cent concentration exhibited minimum mycelial growth $(3.20 \mathrm{~cm})$ with maximum inhibition of mycelial growth $(65.00 \%)$.

\section{References}

Anonymous (2018), Agriculture Indiasat, Department of Statistics, Government of India.

APEDA Annual report. (2019). Ministry of Commerce \& Industry, Government of India.

Chavan, R. 2006. Investigation on Root rot [Macrophomina phaseolina (Tassi)
Goid] of Cotton (Gossipium herbaceum L.). M.Sc., Thesis. JAU, Junagadh.

Dhingani, J.C., Solanki, K.C. and Kansara, S.S. 2013. Management of root rot disease [Macrophomina phaseolina (Tassi) Goid] of Chickpea through botanicals and oilcakes. The Bioscan. 8(3): 739-742.

Jha, A.K. Dubey, S.C. and Jha, D.K. 2000. Evaluation of different leaf extracts and oil cakes against Macrophomina phaseolina causing collar rot of Okra. Journal of Research. 12(2): 225-228.

Kapur, S.P. and Chohan, J.S. 1974. Factors affecting infection and development of fruit rot in papaya by $M$. phaseoli. Indian Phytopathology. 27: 252-253.

Khamari, B., Beura, S.K., Roy, A. and Ranasingh, N. 2017. Assessment of antifungal potency of some plant extracts against Macrophomina phaseolina, causing stem and root rot of sesame. The Bioscan. 12(4): 20472051.

Meena, P.N., Tripathi, A.N., Gotyal B.S. and Satpathy S. 2014. Bio-efficacy of phytoextracts and oilcakes on Macrophomina phaseolina (Tassi.) on stem rot disease of jute, Corchorus spp. Journal of Applied and Natural Science. 6(2): 530-533.

Ray, A. and Kumar, P. 2008. Evaluation of fungicides against Rhizoctonia solani Kuhn, the incidence of aerial blight of Soybean. Pantnagar Journal of Research. 6(1): 42-47.

Varma, J. and Dubey, N.K. 1999. Prospectives of botanical and microbial products as pesticides of tomorrow. Current Science. 76(2): 172-179.

Vincent, J.M. 1947. Distortion of fungal hyphae in presence of certain inhibitors. Nature. 150-850. 


\section{How to cite this article:}

Kanmani, S., N. Rajinimala, J. Sheela and Jeberlin Prabina, B. 2020. Bio- efficacy of Oilcake Extracts to Control Macrophomina phaseolina (Tassi) Goid Causing Dry Root Rot Disease in Groundnut (Arachis hypogaea L.). Int.J.Curr.Microbiol.App.Sci. 9(08): 1190-1195. doi: https://doi.org/10.20546/ijcmas.2020.908.132 